\title{
Analisis Faktor-Faktor yang Mempengaruhi Investasi di Indonesia Tahun 1990 - 2017
}

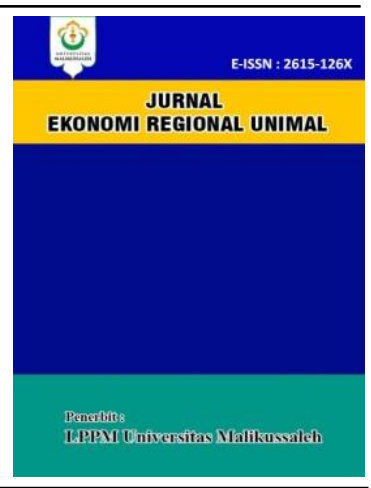

\author{
Rauzatul Jannah ${ }^{* a}$, Asnawi ${ }^{* b}$ \\ *Fakultas Ekonomi dan Bisnis Universitas Malikussaleh \\ a Corresponding author:rauzatu1005@gmail.com \\ b asnawi@unimal.ac.id
}

ARTICLE INFORMATION ABSTRACT

Keywords:

Interest Rates, Inflation, Exchange

Rates, Economic Growth,

Investment.
This study aims to analyze the influence of interest rates, inflation, exchange rates and economic growth on investment in Indonesia from 1990 to 2017. Uses time saries data in the year 1990-2017. The data analysis method used is multiple linear regression. The results show that interest rates have a negative and significant effect on investment in Indonesia, Inflation has no effect on investment in Indonesia, Exchange rates had a positive and significant effect on investment in Indonesia, Economic growth had a negative and significant effect on investment in Indonesia. Simultaneously, interest rates, inflation, exchange rates and economic growth influenced investment in Indonesia.

\section{PENDAHULUAN}

Pertumbuhan investasi di Indonesia sangat dibutuhkan. Indonesia sebagai salah satu negara berkembang masih banyak memerlukan investasi untuk meningkatkan produktivitas ekonominya, investasi dalam perekonomian memegang perananan penting sebagai penggerak ekonomi di suatu negara, perlunya pertumbuhan investasi di Indonesia agar terciptanya lapangan pekerjaan karna itu salah satu masalah yang dihadapii oleh hampir seluruh daerah di Indonesia adalah tingginya tingkat pengangguran. Oleh karena itu dengan tumbuhnya investasii di Indonesia maka terciptanya lapangan kerja dan meningkatkan pendapatan masyarakat serta komsumsi masyarakat, ini menjadi salah satu faktor pentiing dalam mendukung pertumbuhan ekonomi.

Pada kenyataannya investasi di indonesia empat tahun terakhir ini rendah, tinggi rendahnya investasi dipengaruhi oleh beberapa faktor seperti suku bunga, inflasi, kurs dan pertumbuhan ekonomi. Pada tahun 2014 ke tahun 2015 peningkatan investasinya sangat kecil yaitu $-4,91 \%$ kemudian pada tahun 2016 ke tahun 2017 peningkatan invetasinya sebesar 4,46\%, sebenarnya peningkatan pertumbuhan investasi yang besar dapat membangun pertumbuhan ekonomi.
Suku bunga yang tinggi dapat menurunkan ınvestasi di indonesia karena para investor tidak lagi menginveskan investasinya dalam bentuk sektor riil tetapi sudah menyimpan uang ke bank, juga ditambah dengan kurangnya investasi asing ke indonesia (FDI) oleh sebabnya adanya resiko pertumbuhan ekonomi yang rendah. Namun pada tahun 2017 investasi di indonesia mengalami peningkatan yaitu 4,46\% akan tetapi suku bunga pada tahun 2017 juga meningkat yaitu $6 \%$. (Statistik Indonesia, 2019). Hal ini tentu tidak sejalan dengan teori yang dinyatakan oleh Sukirno (2010) yaitu apabila suku bunga tinggi, maka investasi akan rendah, sebaliknya suku bunga yang rendah akan mendorong lebih banyak investasi.

Selanjutnya peningkatan inflasi juga dapat menurunkan investasi (Tandelilin 2010), hal ini dikarenakan apabila inflasi menurun sebenarnya dapat meningkatkan investasi karena jumlah uang beredar akan berkurang. Namun di Indonesia pertumbuhan inflasi tinggi dan pertumbuhan investasi rendah, ini akan mengakibatkan jumlah uang beredar akan meningkat.

Meningkatnya inflasi di indonesia berdampak pada rendahnya pertumbuhan investasi pada tahun 2015 ke tahun 2014 senilai $-4,91 \%$ jumlah tersebut tidak mampu mendorong peningkatan di sektor riil. Karena pertumbuhan investasi kecil dan 
inflasi besar membawa pengaruh besar terhadap pertumbuhan ekonomi di indonesia pada tahun 2014 sebesar 5,02\%. Seharusnya jika investasi di suatu negara meningkat, itu akan mendorong pertambahan pendapatan nasional (pertumbuhan ekonomi).

Namun pada tahun 2017 inflasi di Indonesia meningkat yaitu 3,61\% di bandingkan 2016 akan tetapi investasi di indonesia justru ikut meningkat yaitu 4,46 \% (Statistik Indonesia, 2019). Hal ini berbanding terbalik dengan teori dimana secara teori apabila meningkatnya inflasi maka akan menurunkan investasi karena inflasi dapat meningkatkan biaya perusahaan.

Kurs yang tinggi akan berdampak pula pada investasi yaang rendah(Sukirno, 2010). Namun pada tahun 2017 kurs di Indonesia meningkat yaitu Rp. 15.750/Dollar di bandingkan 2016 akan tetapi investasi di indonesia justru ikut meningkat yaitu 4,46 \% (Statistik Indonesia, 2019). Hal ini tidak sejalan dengan teori dimana secara teori apabila meningkatnya kurs maka akan menurunkan investasi.

Pertumbuhan ekonomi juga menjadi faktor yang menyebabkan tingginya investasi di Indonesia. Namun pada tahun 2017pertumbuhan ekonomi menurun sebesar $5 \%$ di bandingkan 2016 akan tetapi investasi di indonesia justru meningkat yaitu 4,46 \% (Statistik Indonesia, 2019). Hal ini tidak sejalan dengan teori dimana secara teori apabila meningkatnya pertumbuhan ekonomi maka akan meningkatkan investasi.

Tujuan penelitian ini adalah untuk mengetahui pengaruh suku bunga, inflasii, kurs, dan pertumbuhan ekonomi terhadap investasi di Indonesia periode tahun 1990 - 2017.

Selanjutnya, bagian kedua dari tulisan ini membahas tinjauan teoritis terkait variabel yang dibahas pada penelitian ini, kemudian bagian ketiga memaparkan metode dan langkah-langkah yang dilakukan untuk menganalisis pengaruh suku bunga, iinflasi, kurs, dan pertumbuhan ekonomi terhadap investasi di Indonesia. Terakhir, bagian keempat dan kelima akan menjelaskan hasil analisiis yang diperoleh serta kesimpulan dan saran yang dapat dilakukan pada bagian kelima dan keenam.

\section{TINJAUAN TEORITIS \\ Investasi}

Tandelilin (2010) menyatakan bahwa investasi adalah komitmen atas sejumlah dana atau sumber dana dengan tujuan untuk mendapat sejumlah keuntungan di masa yang akan datang. Atau dapat juga didefinisikan sebagai penundaan konsumsi sekarang untuk digunakan di dalam produksi yang efisien dengan harapan dapat memperoleh keuntungan (Hartono).

\section{Suku Bunga}

Menurut Keynes (2012) dikemukakan oleh Chaines dan dinamakan "liquiditi priferensi theori of interest" tingkat bunga ditentukan oleh preferensi dan supply of money.Menurut Samuelson dan William (2004) Suku bunga adalah jumlah uang yang dibayarkan per unit waktu. Weston dan Brigham (2013) suku bunga adalah harga yang dibayarkan atas modal serta keuntungan modal yang merupakan hasil dari suatu equitas dari pendapatan tersebut suku bunga merupakan harga yang dibayarkan dari seseorang kepada orang yang menanamkan uangnya sebagai modal suatu usaha.

\section{Inflasi}

Menurut Nanga (2005), menyatakan bahwa inflasi adalah suatu gejala di mana tingkat hargamengalami kenaikan secara terusmenerus.Sedangkan menurut Boediono (2005), inflasi adalah kecenderungan dari harga-harga untuk menaik secaraterus menerus.

Menurut teori Keynes inflasi terjadi karena masyarakat ingin hidup diluar batas kemampuannya. Teori peningkatan permintaan keseluruhan (agregat demand) yang jauh melebihi jumlah barang yang tersedia. Dalam masyarakat terjadi celah atau kekurangan barang-barang akibat pengaruh inflasi (inflationary gap). Golongan - golongan masyarakat berusaha memperebutkan persediaan barang yang ada dan memperoleh dana untuk dapat membeli barangbarang tersebut. Akibatnya, harga-harga akan naik dan terjadilah inflasi. Inflasi akan tetap berlangsung selama masih ada gap. 
Kurs

Menurut Sukirno (2010), kurs merupakanbanyaknya rupiah yang dibutuhkan untuk memperoleh satu unit mata uang asing. Kurs adalah nilai tukar mata uang terhadap mata uang negara lainnya (Oktavia, 2013).

\section{Pertumbuhan Ekonomi}

Menurut Todaro (2006), pertumbuhan ekonomi adalah proses kenaikan output dalam jangka panjang. Tekanannya pada tiga aspek, yaitu : proses, output perkapita dan jangka panjang.

\section{Kerangka Konseptual}

Berdasarkan tinjauan pusta sebelumnya yang diuraikan, maka kerangka konseptual dalam penelitian ini adalah suku bunga, inflasi, kurs dan pertumbuhan ekonomi merupakan faktor-faktor yang mempengaruhi investasi di Indonesia.

Berikut gambaran kerangka konseptual penelitian:

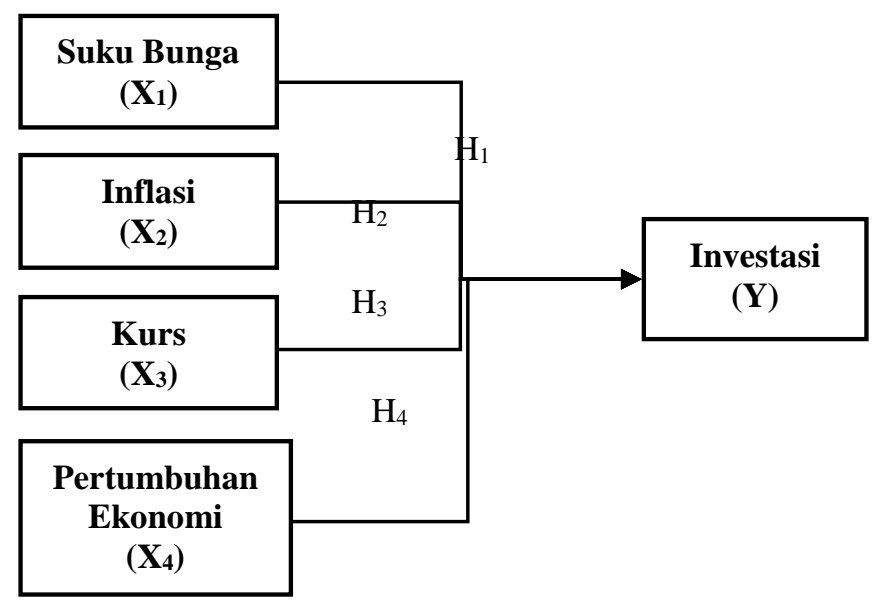

\section{Gambar 1}

Kerangka Konseptual

Berdasarkan kerangka konseptual di atas yang merupakan variabel bebas (independen) adalah variabel suku bunga $\left(\mathrm{X}_{1}\right)$, inflasi $\left(\mathrm{X}_{2}\right)$, kurs $\left(\mathrm{X}_{3}\right)$ dan pertumbuhan ekonomi $\left(\mathrm{X}_{4}\right)$, sedangkan yang merupakan variabel terikat (dependen) adalah variabel investasi $(\mathrm{Y})$.

Dalam kerangka konseptual di atas digambarkan pengaruh masing-mazing variabel independen yaitu suku bunga, inflasi, kurs dan pertumbuhan ekonomi terhadap variabel dependen investasi yang akan di uji dengan uji t. Dan pengaruh secara bersama-sama variabel independen suku bunga, inflasi, kurs dan pertumbuhan ekonomi terhadap investasi yang akan di uji menggunakan uji $\mathrm{F}$.

\section{Hipotesis}

Berdasarkan kerangka konseptual di atas, adapun hipotesis penelitian ini adalah sebagai berikut:

$\mathrm{H}_{1} \quad$ :Diduga suku bunga berpengaruh terhadap investasi di Indonesia.

$\mathrm{H}_{2}$ : Diduga inflasi berpengaruh terhadap investasi di Indonesia.

$\mathrm{H}_{3} \quad$ : Diduga kurs berpengaruh terhadap investasi di Indonesia.

$\mathrm{H}_{4}$ : Diduga pertumbuhan ekonomi berpengaruh terhadap investasi di Indonesia.

$\mathrm{H}_{5}$ : Diduga Suku bunga, inflasi, Kurs dan pertumbuhan ekonomi berpengaruh terhadap investasi di Indonesia.

\section{METODE PENELITIAN}

\section{Data dan Sumber data}

Jenis data yang dipakai dalam pengertian ini adalah Data Sekunder yang digunakan berupa time series. Data time series (data deretan waktu) adalah data yang dilakukan selama suatu periode/jangka waktu tertentu' (Firdaus, 2011). Jenis data dalam penelitian ini adalah data sekunder bulanan, yang meliputi: data yang mengenai nilai tukar yang diperoleh dari Stasistik Ekonomi, Bank Indonesia tahun 1990-2017, data Inflasi, Suku Bunga dan Kurs diambil dari data tahunan periode 1990-2017 yang terdapat pada Bank Indonesia Data Sekunder diperoleh dengan metode pengamatan selama tahun 1990 sampai dengan tahun 2017.

\section{Metode Analisis Data}

Analisis data adalah kegiatan mengolah data yang terkumpul kemudian dapat memberikan interpretasi pada hasil-hasil tersebut. Metode analisis data yang digunakanadalah Analisis Regresi Linear Bergandaa. Sebelum dianalisis dengan regresi linear berganda, data dalam penelitian ini terlebih dahulu di uji dengan uji normalitas dan uji asumsi klasik. 


\section{Uji Normalitas}

Uji normalitas dilakukan untuk menguji apakah didalam model regresi, variabel independen dan dependen terdistribusi normal atau tidak. Uji normalitas bertujuan untuk mengetahui apakah data sudah menyebar secara normal dan mengetahui kenormalan error term dari variabel bebas maupun terikat. Jika data tidak menyebar secara normal maka hasilnya tetap tidak bias, namun tidak lagi efisien.

Jika suatu variabel terdistribusikan secara normal maka koefisien $\mathrm{S}=0$ dan $\mathrm{K}=3$. Sebab itu, residual akan terdistribusi secara normal apabila nilai statistik J-B sama dengan nol. Dan nilai J-B ini didasarkan pada distribusi chi-squares dengan derajat kebebasan (df). Hipotesis yang digunakan adalah:

Ho : Data berdistribusi normal

Ha : Data tidak berdistribusi normal

Kriteria pengujian:

a. Ho ditolak, jika nilai probabilitas $<\alpha 5 \%$. Artinya bahwa residual mempunyai distribusi normal karena nilai statistik J-B tidak sama dengan nol.

b. Ho diterima, jika nilai probabilitas $>\alpha$ 5\%. Artinya bahwa residual mempunyai distribusi normal karena nilai statistik J-B mendekati nol.

\section{Pengujian Asumsi Klasik}

Analisis yang dilakukan untuk menilai apakah di dalam sebuah model regresi linear Ordinary Least Square (OLS) terdapat masalahmasalah asumsi klasik. Berdasarkan keadaan tersebut didalam ilmu ekonometrika agar suatu model dikatakan baik maka perlu dilakukan uji sebagai berikut :

\section{Uji Autokorelasi}

Pengujian ini untuk mengetahui ada atau tidaknya korelasi antara data dalam variabel pengamatan. Untuk melihat adanya autocorelasi dengan menggunakan metode Breusch-Godfrey dan sering dikenal dengan nama metode Lagrange Multiplieer (LM). Metode ini merupakan pengembangan dari metode Durbin-Watson.

Hipotesis yang digunakan untuk menguji ada tidaknya autocorelasi yaitu : a. Ho ditolak, jika Obs*R-squared ( $\chi^{2}$ hitung) $>\left(\chi^{2}\right.$ tabel $)$, atau probabilitasnya $<\alpha=0.05$. Ini menunjukkan adanya masalah autocorelasi didalam model.

b. Ho diterima, jika Obs*R-squared $\left(\chi^{2}\right.$ hitung $)<\left(\chi^{2}\right.$ tabel $)$, atau probabilitas $>\alpha$ $=0.05$. Berarti tidak adanya masalah autocorelasi dalam model.

\section{Uji Heteroskedastisitas}

Uji heteroskardasitas terjadi ketika varians dari residual pengamatan satu ke residual pengamatan yang lain tetap. Untuk melihat ada atau tidaknya heteroskardasitas dapat dilihat melalui Uji White. Dalam pengujian heteroskardasitas Uji White merumuskan hipotesis sebagai berikut :

Ho : tidak terdapat heteroskardasitas

$\mathrm{Ha}$ : terdapat heteroskardasitas

Kriteria pengujian heteroskardasitas adalah :

a. Ho ditolak, jika nilai Obs* $\mathrm{R}$ square $\left(\lambda^{2}\right.$ hitung) $>\lambda^{2}$ tabel. Maka terdapat masalah heteroskardasitas.

b. Ho diterima, jika nilai Obs*R square $\left(\lambda^{2}\right.$ hitung) $<\lambda^{2}$ tabel. Maka tidak ada masalah heteroskardasitas.

Selain itu dapat dilihat juga apabila nilai probabilitas Obs*R square lebih besar dari $\alpha(5 \%)$ maka data bersifat heteroskardasitas. Sebaliknya bila probabilitas Obs*R square lebih kecil dari $\alpha$ $(5 \%)$ maka bersifat tidak heteroskardasitas.

\section{Uji Multikolinearitas}

Uji multikolineritas digunakan untuk mengetahui adanya hubungan linier antar variabel dependent dalam model regresii atau untuk menguji ada tidaknya hubungan yang sempurna atau tidak sempurna diantara beberapa atau semua variabel yang menjelaskan. Ada beberapa cara untuk menganalisis ada atau tidaknya pengaruh multikolineritas dalam penelitian ini yaitu :

a. $\mathrm{R}^{2}$ relatif tinggi $(0,70-1,00)$ tetapi hanya sebagian kecil atau bahkan tidak ada variabel bebas yang signifikan menurut ttest, maka diduga terdapat multikolineritas.

b. Koefisien determinasi individual $\left(\mathrm{r}^{2}\right)$ relatif tinggi dari pada koefisien 
determinasi serentak $\left(\mathrm{R}^{2}\right), \quad$ maka cenderung terdapat multikolineritas.

c. Mengamati nilai Varians Inflation Factor (VIF) pada model regresi, jika VIF $\geq 10$ maka terjadi multikolineritas.

Pada penelitian ini dalam mendeteksi gejala multikolineritas adalah dengan mengamati nilai Varians Inflation Factor (VIF) pada model regresi. Data dapat dikatakan terbebas dari gejala multikolineritas jika nilai VIF antar variabel independent lebih kecil dari 10.

\section{Pengujian Statistik}

Untuk menguji kebenaran model regresi diperlukan pengujian statistik diantaranya :

\section{Uji t-statistik}

Uji t-statistik dilakukan untuk menjelaskan pengaruh variabel bebas secara individu memberikan pengaruh atau tidak terhadap variabel terikat. Dengan menggunaka derajat signifikan $5 \%$, hipotesis yang akan diuji dalam penelitian ini adalah :

$\mathrm{H}_{1}$ : Diduga Diduga Suku bunga berpengaruh terhadap investasi di Indonesia.

$\mathrm{H}_{2}$ : Diduga Inflasi berpengaruh terhadap investasi di Indonesia.

$\mathrm{H}_{3}$ : Diduga Kurs berpengaruh terhadap investasi di Indonesia.

$\mathrm{H}_{4}$ : Diduga Pertumbuhan Ekonomi berpengaruh terhadap investasi di Indonesia.

Kriteria uji t-statistik, $\mathrm{H}_{1}$ di terima dan $\mathrm{H}_{0}$ di tolak jika nilai t-statistik lebih besar dari nilai ttabel $a=5 \%$ dan sebaliknya.

\section{Uji F-statistik}

Uji ini digunakan untuk mengetahui pengaruh variabel independen secara signifikan terhadap variabel dependen. Dimana jika $F_{\text {hitung }}>$ $\mathrm{F}_{\text {tabel}}$, maka $\mathrm{H}_{1}$ diterima atau variabel dependen. Sebaliknya jika $F_{\text {hitung }}<\mathrm{F}_{\text {tabel, }}$, maka $\mathrm{H}_{0}$ diterima variabel independen secara bersama-sama tidak memiliki pengaruh terhadap variabel dependen (tidak signifikan) dengan kata lain perubahan yang terjadi pada variabel terikat tidak dapat dijelaskan oleh perubahan variabel independen, dimana tingkat signifikan yang digunakan adalah 5\%.

\section{Uji Koefisien Determinasi $\left(\mathbf{R}^{\mathbf{2}}\right)$}

Pada $\mathrm{R}^{2}$ diartikan besarnya presentase sumbangan variabel bebas $(\mathrm{X})$ terhadap variabel terikat (Y) sedangkan lainnya merupakan sumbangan dari faktor lainnya yang tidak termasuk dalam model (Rahim,2013).

Nilai koefisien determinasi antara 0 dan 1 . Nilai $\mathrm{R}^{2}$ yang kecil berarti kemampuan variabelbebas dalam menjelaskan variasi variabel terikat amat terbatas.

\section{HASIL PENELITIAN DAN PEMBAHASAN}

\section{Hasil Uji Normalitas}

Berikut adalah hasil uji normalitas yang diperoleh dari program Eviews 9 dapat dilihat pada gambar berikut ini:

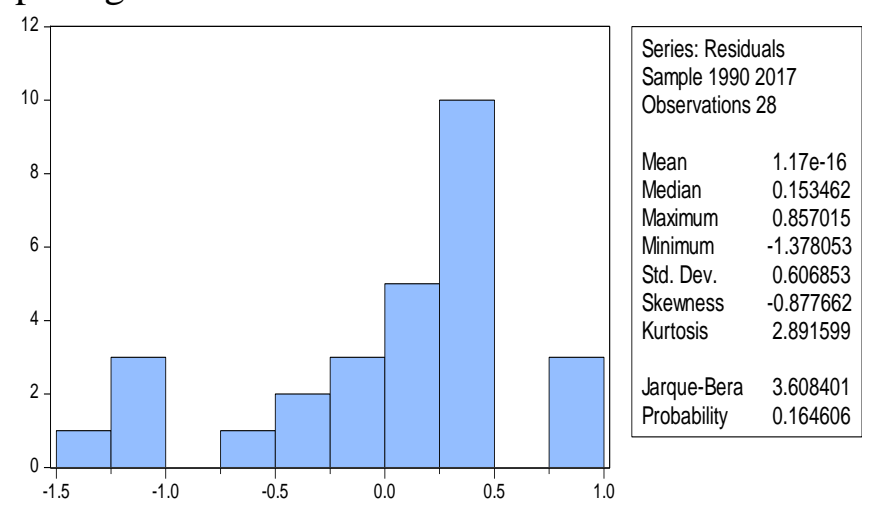

Sumber : Hasil Eviews, data diolah (2019)

Gambar 2

\section{Hasil Uji Normalitas}

Dari gambar diatas dapat dilihat bahwa grafik histrogram dapat membentuk pola distribusi simetris, dengan demikian maka dinyatakan residual terdistribusi normal.

Berdasarkan uji normalitas menunjukkan nilai JB sebesar 3,60 < 11,07 sehingga dapat disimpulkan bahwa data terdistribusi normal.

Hasil dari uji normalitas menunjukkan bahwa nilai Prob JB > 0,05 yaitu sebesar 0,164>0,05 maka dapat disimpulkan bahwa residual berdistribusi normal.

\section{Hasil Uji Asumsi Klasik \\ Hasil Uji Multikolinieritas}

Multikolinieritas ini bertujuan untuk mengetahui apakah maing-masing variabel bebas saling berhubungan secara linier dalam model persamaan regresi yang digunakan. Hasil 
Multikolinieritas dapat dilihat pada Tabel 2 Berikut ini :

\section{Tabel 2 \\ Hasil Uji Multikolinieritas \\ V a riance Inflation Factors

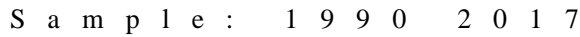 \\ In c luded ob servations: 28}

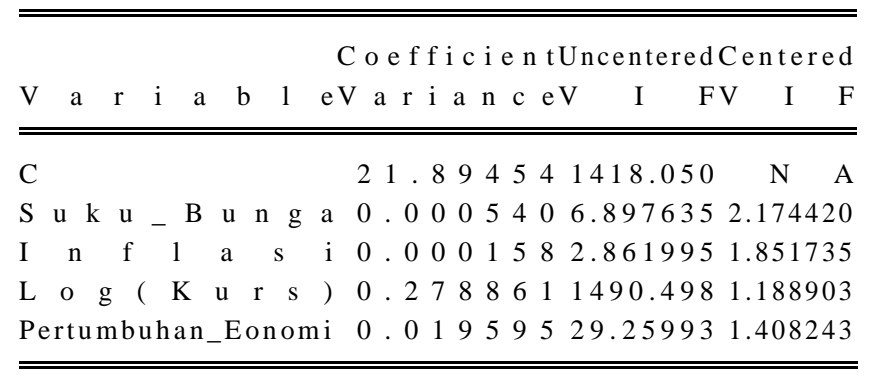

Sumber : Hasil eviews, 2019

Hasil uji multikolinieritas dapat dilihat pada tabel di atas yang menunjukkan bahwa model ini terbebas dari masalah multikolinieritas dimana nilai centered VIF dari variabel suku bunga, inflasi, kurs dan pertumbuhan ekonomi lebih kecil dari 10. Adapun nilai suku bunga $(2,17<10)$, inflasi $(1,85<10)$, Kurs $(1,18<10)$ dan Pertumbuhan ekonomi $(1,40<10)$,

\section{Hasil Uji Autokorelasi}

Berdasarkan hasil uji autokorelasi dengan menggunakan program Eviesw :

\section{Tabel 3}

Hasil Uji Autokorelasi

Breusch-Godfrey Serial Correlation LM Test:

F - s t a t i s t i c 1.340425Prob. F( 2, 21$) 0.2832$ Obs*R - squared3.169811 Prob. Chi-Square(2) 0.2050

Sumber : Data diolah (2019)

Berdasarkan hasil out put Obs * R-squared sebesar 3,16 di bandingkan dengan Chi-Squared tabel pada df (2) sebesar 5,99, maka 3,16 < 5,99 berarti data muncul sudah berbeda sehingga tidak terjadi autokorelasi dalam penelitian. Hal ini juga dapat dilihat dari Pro. Chi Square lebih besar dari 0,05 yaitu 0,205 .

\section{HasilUji Heteroskedastisitas}

Untuk mendeteksi ada tidaknya heteroskedastisita maka dengan membandingkan nilai R-squared dan tabel $\chi^{2}$. a. Jika nilai Obs*R-squared $>\chi^{2}$ (chi-square) tabel, maka tidak lolos dari uji heteroskedastisitas.

b. Jika nilai Obs*R-squared $<\chi^{2}$ (chi-square) tabel, maka lolos dari uji heteroskedastisitas.

\section{Tabel 4}

Hasil Uji Heteroskedastisitas

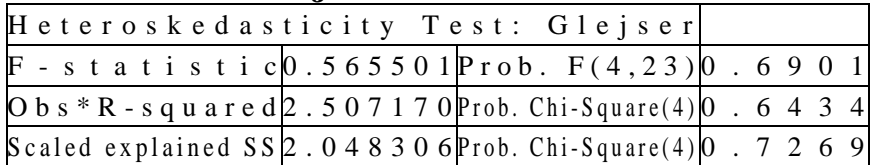

Sumber : Data diolah, (2019)

Dari hasi tabel 4 di atas dapat dilihat nilai obs* R-square untuk hasil estimasi uji glejser adalah sebesar 2,50 dan nilai $\chi^{2}$ tabel dengan derajat kepercayaan 5\% dan df (4) adalah 9,49 karena nilai Obs*R-squared 2,50 < 9,49 maka dapat dikatakan bahwa model diatas lolos dari heteroskedastisitas. Hal ini juga dapat dilihat dari probabilitas Chi-Squared sebesar 0,726, nilai tersebut $0,726>0,05$.

\section{Analisis Regresi Linier Berganda}

Berdasarkan dari hasil Uji analisis regresi linier berganda dengan alat bantu komputer yang menggunakan program Eviews, dapat dilihat pada Tabel 5 :

\section{Tabel 5}

Hasil Analisis Regresi Linier Berganda

Dependent Variable: Log ( Investasi)

V a $r$ i a b 1 eCoefficientStd. Errort-StatisticProb

C 2.7051884.6791610.5781350.5688

S u k u B u n g-0.0525650.023243-2.2615430.0335

I n f 1 a s i-0.0009060.012571-0.0720790.9432

$\mathrm{L}$ o g ( K u r s ) 1.2049610.5280732.2818100.0321

Pertumbuhan_Eonomi-0.3620300.139982-2.5862640.0165

$\mathrm{R}$ - s q u a r e d0.411281 Mean dependent var 11.33141 Adjusted R-squared 0.308895 S.D. dependent var0.790914 S.E. of regression0.657508 Akaike info criterion 2.159713 Sum squared resid9.943291 Schwarz criterion 2.397607 Log like lihood-25.23599 Hannan-Quinn criter.2.232440 F - s t a t i s t i c4.016972 Durbin-Watson stat 1.658449 Prob(F-statistic) 0.012944

Sumber : Eviews 8, data diolah (2019)

Dari tabel 5 di atas maka model regresi linier berganda adalah sebagai berikut :

$$
\mathrm{Y}=2,705188-0.052565 \mathrm{X}_{1}+0.000906 \mathrm{X}_{2}+
$$


Dari hasil diatas dapat di interpretasi hasil analisis regresi linier berganda yaitu:

1. Konstanta sebesar 2,705188 menunjukkan apabila variabel suku bunga, inflasi, kurs dan pertumbuhan ekonomi bernilai nol maka variabel dependen investasi mempunyai nilai sebesar 2,705188 .

2. Koefisien variabel suku bunga mempunyai nilai sebesar - 0.052565 Hal ini menunjukkan hubungan yang negatif. Artinya apabila suku bunga mengalami peningkatan $1 \%$ maka investasi akan mengalami penurunan sebesar $0,05 \%$.

3. Koefisien variabel inflasi mempunyai nilai sebesar -0.000906. Hal ini menunjukkan hubungan yang negatif. Artinya apabila inflasi mengalami peningkatan $1 \%$ maka investasi akan mengalami penurunan sebesar $0,0009 \%$.

4. Koefisien variabel kurs mempunyai nilai sebesar 1.204961. Hal ini menunjukkan hubungan yang positif. Artinya apabila kurs mengalami peningkatan $1 \%$ maka investasi akan mengalami peningkatan sebesar $1,20 \%$.

5. Koefisien variabel pertumbuhan ekonomi mempunyai nilai sebesar -0.362030. Hal ini menunjukkan hubungan yang negatif. Artinya apabila pertumbuhan ekonomi mengalami peningkatan $1 \%$ maka investasi akan mengalami penurunan sebesar $0,36 \%$.

\section{Hasil Pengujian Hipotesis \\ Hasil Uji t}

Adapun hasil pengujian hipotesis di dalam penelitian ini adalah sebagai berikut:

1. Secara parsial suku bunga berpengaruh negatif dan signifikan terhadap investasi di Indonesia. Hal ini ditunjukkan oleh hasil nilai $t$ hitung $>\mathrm{t}$ tabel yakni 2,261 >1,713 dan nilai signifikan sebesar $0.033<0.05$. Dengan demikian penelitian ini menerima $\mathrm{H}_{1}$ yang artinya suku bunga berpengaruh negatif dan signifikan terhadap investasi di indonesia periode 1990 sampai 2017.

2. Secara parsial inflasi tidak berpengaruh terhadap investasi di Indonesia. Hal ini ditunjukkan oleh hasil nilai $\mathrm{t}$ hitung $<\mathrm{t}$ tabel yakni $0,0720<1,713$ dan nilai signifikan sebesar $0.943>$ 0.05. Dengan demikian penelitian ini menolak $\mathrm{H}_{2}$ yang artinya inflasi tidak berpengaruh terhadap investasi di indonesia periode 1990 sampai 2017.
3. Secara parsialkursberpengaruh positif dan signifikan terhadap investasi di Indonesia. Hal ini ditunjukkan oleh nilai $\mathrm{t}$ hitung $>\mathrm{t}$ tabel yakni 2,281 $>1,713$ dan nilai signifikan sebesar $0.032<0.05$. Dengan demikian penelitian ini menerima $\mathrm{H}_{3}$ yang artinya kurs berpengaruh positif dan signifikan terhadap investasi di indonesia periode 1990 sampai 2017.

4. Secara parsial pertumbuhan ekonomi berpengaruh negatif dan signifikan terhadap investasi di Indonesia. Hal ini ditunjukkan oleh nilai $\mathrm{t}$ hitung $>\mathrm{t}$ tabel yakni 2,586 >1,713 dan nilai signifikan sebesar $0.016<0.05$. Dengan demikian penelitian ini menerima $\mathrm{H}_{4}$ yang artinya pertumbuhan ekonomi berpengaruh negatif dan signifikan terhadap investasi di indonesia periode 1990 sampai 2017.

\section{Hasil Uji F}

Dengan ketentuan apabila nilai $\mathrm{F}_{\text {hitung }}>$ dari

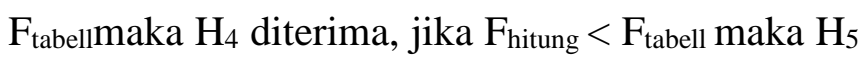
ditolak. Artinya apabila $\mathrm{F}_{\text {hitung }}>$ dari $\mathrm{F}_{\text {tabellmaka }}$ terdapat pengaruh suku bunga, inflasi, kurs dan pertumbuhan ekonomi terhadap investasi. Secara simultan suku bunga, inflasi, kurs dan pertumbuhan ekonomi berpengaruh terhadap investasi dimana $F_{\text {hitung }}>F_{\text {tabell }}$ yaitu 4,016 $>2,795$ dan nilai signifikan sebesar $0.000<0.05$.

\section{Koefisien Determinasi $\left(\mathbf{R}^{2}\right)$ dan Korelasi $(R)$ Koefisien Determinasi $\left(\mathbf{R}^{\mathbf{2}}\right)$}

Berdasarkan Tabel 5 diatas hasil uji Koefisen determinasi $\mathrm{R}^{2}$ dengan regresi linier berganda, maka yang di lihat dari $\mathrm{R}$ Square yaitu sebesar 0,4112 atau $41,12 \%$. Hasil ini berarti suku bunga, inflasi, kurs dan pertumbuhan ekonomi berpengaruh terhadap investasi sebesar $41,1 \%$. Sedangkan sisanya 48,9 \% dipengaruhi oleh faktor-faktor lain.

\section{Koefisien Korelasi (R)}

Hasil yang diperoleh berdasarkan Tabel 5 untuk koefisien determinasi $\left(\mathrm{R}^{2}\right)$ adalah sebesar 0,4112, maka koefisien korelasi (R) adalah sebesar $\sqrt{R^{2}}=$ yaitu 0,6412 . Hasil ini berhubungan kuat secara positif, karena nilai $\mathrm{R}$ mendekati positif (+ 1). 


\section{Pembahasan}

\section{Pengaruh Suku Bunga Terhadap Investasi}

Hasil dari penelitian inisuku bunga berpengaruh negatif terhadap investasi di Indonesia. Di indonesia Suku bunga tertinggi sepanjang tahun 1990 sampai 2017 terjadi pada 1998 dan suku bunga terendah terjadi pada 2014. Tingginya suku bunga disebabkan karena perubahan nilai mata uang rupiah, sehingga investor lebih tertarik menyimpan dana dalam bentuk tabungan. Investasi tertinggi terjadi pada Tahun 2017 yaitu sebesar Rp. 275,321.90 Milyar. Investasi yang tinggi menunjukkan banyaknya investor yang lebih tertarik melakukan investasi pada tahun 2007 karena adanya return yang menjanjikan. Investasi terendah terjadi pada tahun 2008 yaitu Rp. 20.363,40 Milyar. Hal ini menunjukkanapabila suku bunga meningkat maka investasi akan berkurang. Suku bunga yang tinggi dapat menurunkan investasi di indonesia karena para investor tidak lagi menginveskan investasinya dalam bentuk sektor riil tetapi sudah menyimpan uang ke bank, juga ditambah dengan kurangnya investasi asing ke indonesia (FDI) oleh sebabnya adanya resiko pertumbuhan ekonomi yang rendah.

\section{Pengaruh Inflasi Terhadap Investasi}

Hasil dari penelitian ini menunjukkan bahwa inflasi tidak berpengaruh terhadap investasi di Indonesia. Hal ini menunjukkan bahwa apabila inflasi meningkat maka tidak akan memberikan perubahan pada investasi. Inflasi yang terjadi di Indonesia pada tahun 1990 sampai 2017 berfluktuasi. Inflasi tertinggi terjadi pada Tahun 1998 yaitu sebesar 77,6 \%. Tingginya inflasi disebabkan karenakrisis finansial yang terjadi di indonesia. Sementara inflasi terendah yaitu sebesar 1999 yaitu $2 \%$.

Tidak adanya pengaruh antara inflasi terhadap investasi mengindikasikan bahwa apabila terjadi peningkatan atau penurunan terhadap tingkat inflasi belum tentu akan meningkatkan atau menurunkan investasi daerah. Hasil penelitian ini sejalan dengan yang di ungkapkan oleh Siregar (2016) dimana faktor penyebab tidak adanya pengaruh antara inflasii dan investasi karena adanya Demand Pull Inflation. Dengan adanya kelebihan permintaan terhadap barang dan jasa yang melebihi jumlah yang bisa dihasilkan perekonomian maka kenaikan harga akan terjadi. Tetapi sekalipun harga barang maupun jasa mengalami kenaikan, pihak pengusaha akan tetap berusaha untuk memproduksi barang semaksimal mungkin, sehingga dengan keadaan ini tidak menyurutkan investor untuk tetap berinvestasi, sehingga inflasi tidak begitu mempengaruhi investasi.

Hasil ini juga sama dengan hasil Penelitian Sasana (2008) dan Siregar (2016) yang mengatakan bahwa inflasi tidak berpengaruh dengan investasi.

\section{Pengaruh Kurs Terhadap Investasi}

Hasil dari penelitian ini menunjukkan bahwa Kurs berpengaruh positif terhadap investasi di Indonesia. Hasil penelitian tersebut sesuai dengan pendapatan Shikawa (2004) yang menyatakan bahwa Kurs dapat berpengaruh pada dua sisi yaitu sisi permintaan dan sisi penawaran.

Kurs selama tahun 1990 sampai 2017 berfluktuasi. Kurs tertinggi terjadi pada Tahun 2017 yaitu Rp. 15.750 . sementara kurs terendah terjadi pada tahun 1990 yaitu 4.300. Tingginya kurs di sebabkan karena tingginya nilai mata uang rupai dalam negeri, sementara kurs yang rendah di sebabkan karena nilai mata uang rupiah lebih rendah di bandingkan dengan mata uang luarr negeri.

\section{Pengaruh Pertumbuhan Ekonomi Terhadap Investasi}

Hasil dari penelitian ini menunjukkan bahwa pertumbuhan ekonomi berpengaruh negatif terhadap investasi di Indonesia. Apabila pertumbuhan ekonomi meningkat maka investasi akan menurun. Hal ini menunjukkan bahwa pertumbuhan ekonomi menyebabkan investasi dalam negeri yang rendah. Walaupun terjadi peningkatan pada pertumbuhan ekonomi tetapi tidak menyebabkan meningkatnya investasi. Hal ini menandakan bahwa masih kurang adanya kepercayaan investor dalam negeri untuk menanamkan modalnya.

Pertumbuhan ekonomi indonesia selama tahun 1990 sampai 2017 berfluktuasi.tingginya pertumbuhan ekonomi terjadi pada tahun 2010 
yaitu 6,81\%. Sementara peryumbuhan ekonomi terendah terjadi pada tahun 1998 yaitu 3,2\%. Rendahnya pertumbuhan ekonomi pada tahun 1998 di sebabkan karena terjadinya krisis global yang melanda indonesia.

\section{KESIMPULAN DAN SARAN}

\section{Kesimpulan}

Berdasarkan hasil penelitian dan pembahasan, maka peneliti mengemukakan kesimpulan sebagai berikut :

1. Secara parsial suku bunga berpengaruh negatif dan signifikan terhadap investasi di Indonesia periode 1990 sampai 2017.

2. Secara parsialinflasi tidak berpengaruh terhadap investasi di Indonesia periode 1990 sampai 2017.

3. Secara parsial kurs berpengaruh positif dan signifikan terhadap investasi di Indonesia periode 1990 sampai 2017.

4. Secara parsial pertumbuhan ekonomi berpengaruh negatif dan signifikan terhadap investasi di Indonesia periode 1990 sampai 2017.

5. Secara simultan suku bunga, inflasi, kurs dan pertumbuhan ekonomi berpengaruh terhadap investasi di Indonesia periode 1990 sampai 2017.

\section{Saran}

Adapun saran yang dapat diberikan penelitiadalah sebagai berikut :

1. Hendaknya pemerintah dapat mempertahankan nilai tukar rupiah dalam batas yang wajar, sebab jika nilai rupiah terlalu tinggi maka investasi akan meningkat.

2. Hasil analisis yang dilakukan pada penelitian ini masih bersifat agregat dan masih menunjukkan adanya faktor-faktor lain yang tidak terdapat pada model persamaan yang digunakan.

\section{DAFTAR PUSTAKA}

Adisasmita, R. (2013). Teori-Teori Pembangunan Ekonomi. Yogyakarta: Graha Ilmu

Ahmad, K. (2004). Dasar-Dasar Manajemen Investasi dan Portofolio. Edisi Revisi. Penerbit Rineka Cipta: Jakarta

Arifin, I. (2009). Faktor yang Mempengaruhi Nilai Tukar Rupiah.

Atmaja, A. (2002). Inflasi di Indonesia: SumberSumber Penyebab dan Pengendaliannya".Jurnal Akuntansi dan Keuangan. Vol.1, No.1, BPFEUGM

Case, Karl E. dan Ray, C.F. (2009). PrinsipPrinsip Ekonomi Makro. Edisi Kelima. Jakarta: PT. Indeks

Ditha.R.K. (2011).Analisis Pengaruh Investasi, Inflasi ,dan Suku Bunga Terhadap Pertumbuhan Ekonomi. http://eprints.upnjatim.ac.id, di akses tanggal 12 Agustus 2015.

Firdaus, M. (2011). Ekonometrika Suatu Pendekatan Aplikatif.Edisi Kedua. Jakarta: Bumi Aksara

Ghozali, I. (2005). Aplikasi Analisis Mulitivariate dengan Program SPSS. Edisi Ketiga. Universitas di Penegoro. Semarang.

Henry, S. (2000).Basis Pengambilan Keputusan Bisnis.Jakarta: Salemba Empat.

Hartono, J. (2000). Teori portofolio dan Analisis Investasi.Edisi Kedua. Yogyakarta: UPP AMP YKPN

Kenynes, J. (1936). The General Theory Of Employment, Interest and Money. London: Macmillan

Khalwaty, T. (2000). Inflasi dan Solusinya. Jakarta : PT Gramedia Pustaka Utama

Madura, J. (2003). International Financial Management. USA: Thompson Higher Education

Mankiw, N. G. (2006). Macroeconomics. Edisi ketiga. United States of America: Worth Publishers, Inc.

Meihendra,T.D. (2009). Analisis Keterbukaan Ekonomi Terhadap Nilai Tukar di Indonesia.

Mishkin, F S. (2008). Ekonomi, Uang, Perbankan dan Pasar Keuangan.Edisi 8. Buku 2. Jakarta: Salemba Empat.

Murni, A. (2006). Ekonomi Makro.Bandung: PT Refika Aditama

Nanga, M. (2005). Makro Ekonomi, Teori, Masalah, dan Kebijakan.Edisi Kedua. Jakarta: PT Raja Grafindo Persada. 
Nopirin. (2006). Ekonomi Moneter. Buku Satu. Edisi Ketiga. Yogyakarta :

Oktavia, (2013). Analisis Kurs dan Money Supply di Indonesia. Jurnal kajian ekonomi. Vol.1.No.02. Padang: Universitas Negeri Padang

Putong, I. (2002). Ekonomi Mikro dan Makro. edisi kedua, ghalia indonesia. Jakarta

Rahardja, P dan Mandala, M. (2008). Teori Ekonomi Makro.Edisi Keempat. Jakarta: Lembaga Penerbit FE UI

Samuelson, P.A dan William, D.N. (2004). Ilmu Makroekonomi.Edisi Bahasa Indonesia. Jakarta: PT Media Global Edukasi

Situmeang, C. (2010). Manajemen Keuangan Internasioanal. Bandung: Citaputaka Media Perintis

Sugiyono. (2008). Metode Penelitian Bisnis.Bandung: Alfa Beta

Sukirno, S. (2010). Makro Ekonomi. Edisi ke-1, Rajawali Pers, Jakarta

Sunariyah. (2006). Pengantar Pengetahuan Pasar Modal.Edisi Kelima. Yogyakarta: UPP STM YKPN

Tandelilin, E. (2011). Analisis Investasi dan Manajemen Portofolio. Yogyakarta: BPFE

Todaro, M. P. (2006) Pembangunan Ekonomi. Edisi Kesembilan. Jakarta: Erlangga

Winardi. (2006). Pengantar Ilmu Ekonomi.Edisi ketujuh. Penerbit Tarsito, Bandung 